\title{
Influence of rivers on geotemperatures
}

\author{
F. MON(*ietiai $(*)$
}

Rieevuto il 10 Settembre 1970

Sumsary. - An estimation is marte of the thermal disturbance that the eventual differone between the mean annual temperuture of a rives and that of the ground woukl cause on the normal gesthermal field.

Riassunto, - Viene eseguita una stima del disturlo termico che l'evontuale differenza tra temperatura merlia annua di un fume e quella del suolo poirebbe causare sul campo geoternico normale.

\section{TN'TKOUUCTION.}

During a research on the geothermal flow in the Fossa Bradanica (1) it has been necessary to investigate under what conditions and to what extent a river influences the normal geothermal field, nuder the lyypothesis of heat conduction in steady state.

In order that the river provokes a thermal perturbation, it suflices merely for the river to have a mean annual temperature different from that for the ground. Therefore, with the aim of carrying out this type of investigation, it would be just necessary to know the mean annual temperatures of the river and of the soil in the area under examination.

Available literature provides no direct comparisons between these two temperatures. However, they may be obtained by comparison between the temperature of the river water and the air temperature (investigations run by liydrologists) and by comparison between air temperature and that of the ground (made by climatologists and, especially, by auronomists).

(*) Istituto di Geodesia e Geofisica, Universitì - Bari (Italia). 


\section{Conphison of River aNo Am Thmphratures.}

Hydrologists lave not paid much attention to variations in river tomporature (2) and so present knowlexlge is ineomplete.

However, from tho few papers availables (for a briof bibliography sue $(3,4,5))$ on merlium-high latitude areas, there emerge, inter alia, two important factors bearing on the present investigation:

$\left.1^{\circ}\right)$ mean annual river temperatwre aiffers from that of the air, generally being higher

20) the temperature gradient of rivers (with olevation) is also diflerent and generally above that of the air.

In the case of Italy, Tonini (') maintains that the mean annual tempreature of river waters in this climate is some $20^{\circ} \mathrm{C}$ higher than that of the air. Yisentini $\left(^{(}\right)$observed a temperature gradient of about $1^{\circ} \mathrm{C}$ for every $200 \mathrm{~m}$ in the case of surface waters in the Po basin. On comparing this with that of the air $\left(0.4-1^{\circ} \mathrm{C} / 100 \mathrm{~m}\right)$ it will be seen that the difrerente increases with elevation.

\section{Comparison of AUr and Ground Tempelatures.}

The results of these investigations are genorally utilized in geothermal studies for making the topographic correction ( $)$.

If local climatic eonditions present no particular fealures and if there are no shablow groundwaters in movement and there is no ovatyoration, it is generally held that, in the case of clevations which are not too high, the mean anmual air and ground temperatures can be considered caual or rlifter by no more than a fow tonths of a degree centigrade, the groumel surfuce temperature boing ligher than that of the air.

In mountain regions, on the other land, this difierence increases with elevation, since the air temperature gradient is greater than that of the ground.

Exhanstive references on eomparisons of air-ground temperaturess in Italy are given in works by the agronomists Seotton $\left({ }^{8}\right)$ and Mactehia $\left({ }^{9}\right)$. Mention of the results of air and ground temperature grudients in the Alps and the Fossit Roralanica are in the works of Birth (7) and Hongetlli and Ricohetti (1). 
It is apparent that in general the mean temperature of rivar wator is higher than that of the air, and that the mean temporature of the air is lower than that of the gromed. Since it is unlikely that these two will balauce ont exactly, it is to bo expected that there will be a dilterenee botwoen the temperibtiuc of river water aul that of the gromend, and that this may be of the order of a few degrees.

In all probability this fact will have no influense on the temperature readings taken in bores a considerable distance from rivers, lut the disturbance in holes fairly nearloy must be assesserl.

Sines tho absolute value of the disturbanes camot ba calculated, we estimate its peroontage valuo, that is the ratio between its value and. tho differenes betwoon the mean annual temperature of the river and that of tho soil.

\section{THEORY.}

The temperaturo under stationary eomditions at any given point of a semi-infunite solid, wlooso surfice ooincides with plane $x y$ (itxis $z$ being orionted towards tho inner part of the borly) and with a surface tenuprature is $F\left(x^{\prime}, y^{\prime}\right)$, is givon by the following expression (10):

$$
T(x, y, z)=\frac{1}{2 \pi} \int_{-\infty}^{\infty} d x^{\prime} \int_{-\infty}^{\infty} \frac{z \cdot F\left(x^{\prime}, y^{\prime}\right)}{\left[\left(x-x^{\prime}\right)^{2}+\left(y-y^{\prime}\right)^{2}+z^{2}\right]^{3 / 2}} d y^{\prime} .
$$

Expression [1] can also bo applied when the surface temperature is $F^{\prime}\left(x^{\prime}, y^{\prime}\right)$ in a given zone $S$ and nil over the remainder of the surface. This given zone may represent the area oceupied by a river having any form; in which case:

$$
T(x, y, z)=\frac{1}{2} \frac{1}{\pi} \int_{S}^{2} \frac{z \cdot F\left(x^{\prime}, y^{\prime}\right) d x^{\prime} d y^{\prime}}{\left[\left(x--x^{\prime}\right)^{2}+\left(y--y^{\prime}\right)^{2}+z^{2}\right]^{3 / 2}} .
$$

Let us assiune that near a borehole $P$ (Fig. 1) the river an be eonsidorod as being straight, is $L$ metres wide and only a fow motres deep, and that the river-ground mean annual temperature diflerence is $T_{o}$. 
In a reference system like that in Fig. 1, if $F\left(x^{\prime}, y^{\prime}\right)$ is nil over the whole of the plane $x y$, excluding the field given by $0<x<L$, where is $T_{a}$, then [1] may be written:

$$
T(x, y, z)=\frac{z T_{0}}{2 \pi} \int_{-\infty}^{m} d x^{\prime} \int_{L}^{o} \frac{d y^{\prime}}{\left[\left(x-x^{\prime}\right)^{2}+\left(y-y^{\prime}\right)^{2}+z^{2}\right]^{3 / 2}}
$$

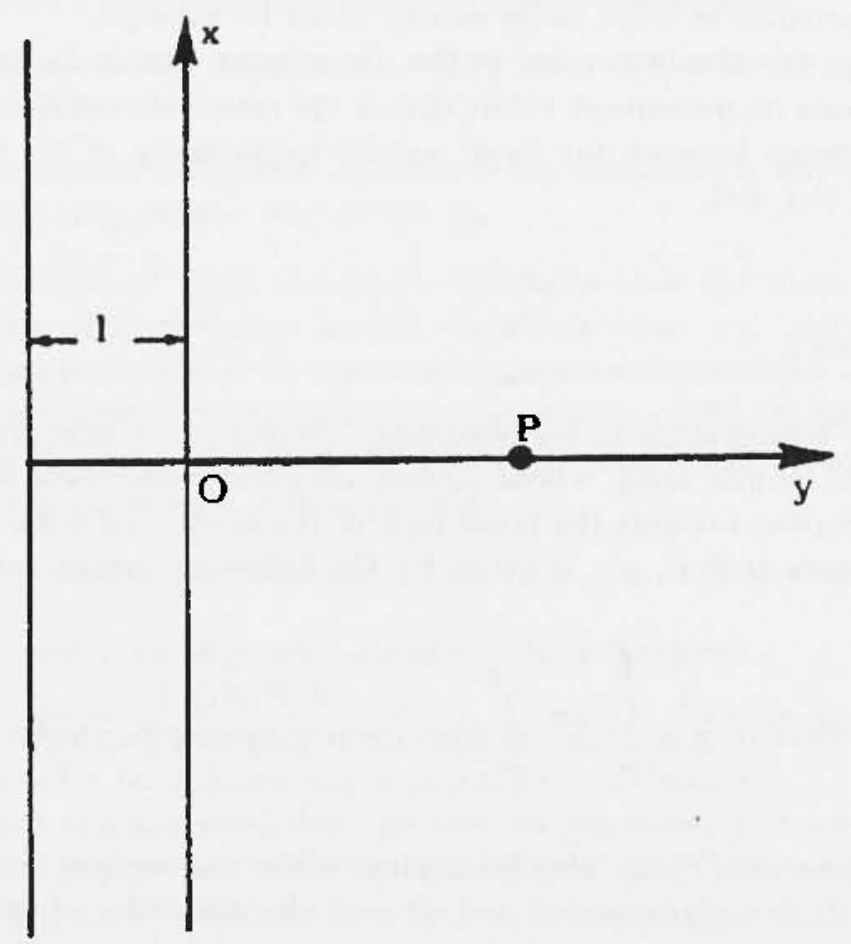

Fig. L - Coordinates System for ploting the influence of a river on the temperature distribution of the soil.

which, on integrating gives:

$$
\frac{T}{I_{a}}=\frac{1}{\pi}\left(\operatorname{arctg} \frac{y+L}{z}-\operatorname{arctg} \frac{y}{z}\right)
$$

where $y$ is the distance from the bore to the nearest bank, $z$ is the depth. 
By way of example, Fig. 2 gives the percentage disturbance $\frac{T}{I_{0}}$ caused in a section of ground at right angles to a river with width $L=100 \mathrm{~m}$.

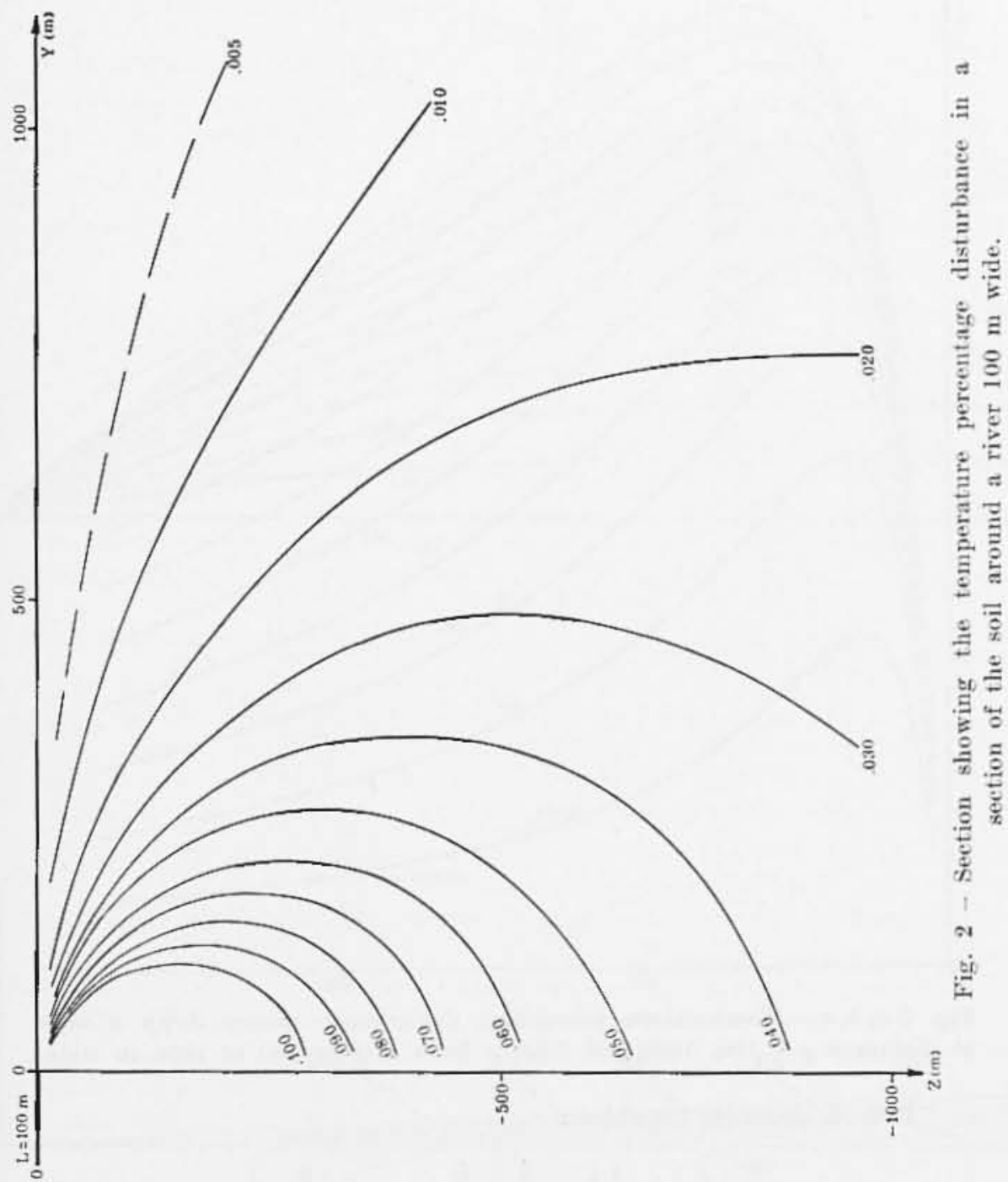


Figs. $3 a, b$ and $c$ which show the pereentage disturbance caused down a bore at distances $y=100,1000$ and $5000 \mathrm{~m}$ from a river 100 to $1000 \mathrm{~m}$ wide, indicate more elesrly the existenee of a $\frac{T}{I_{0}}$ maximum which shifts to over greater deptli as $y$ and $L$ increase.

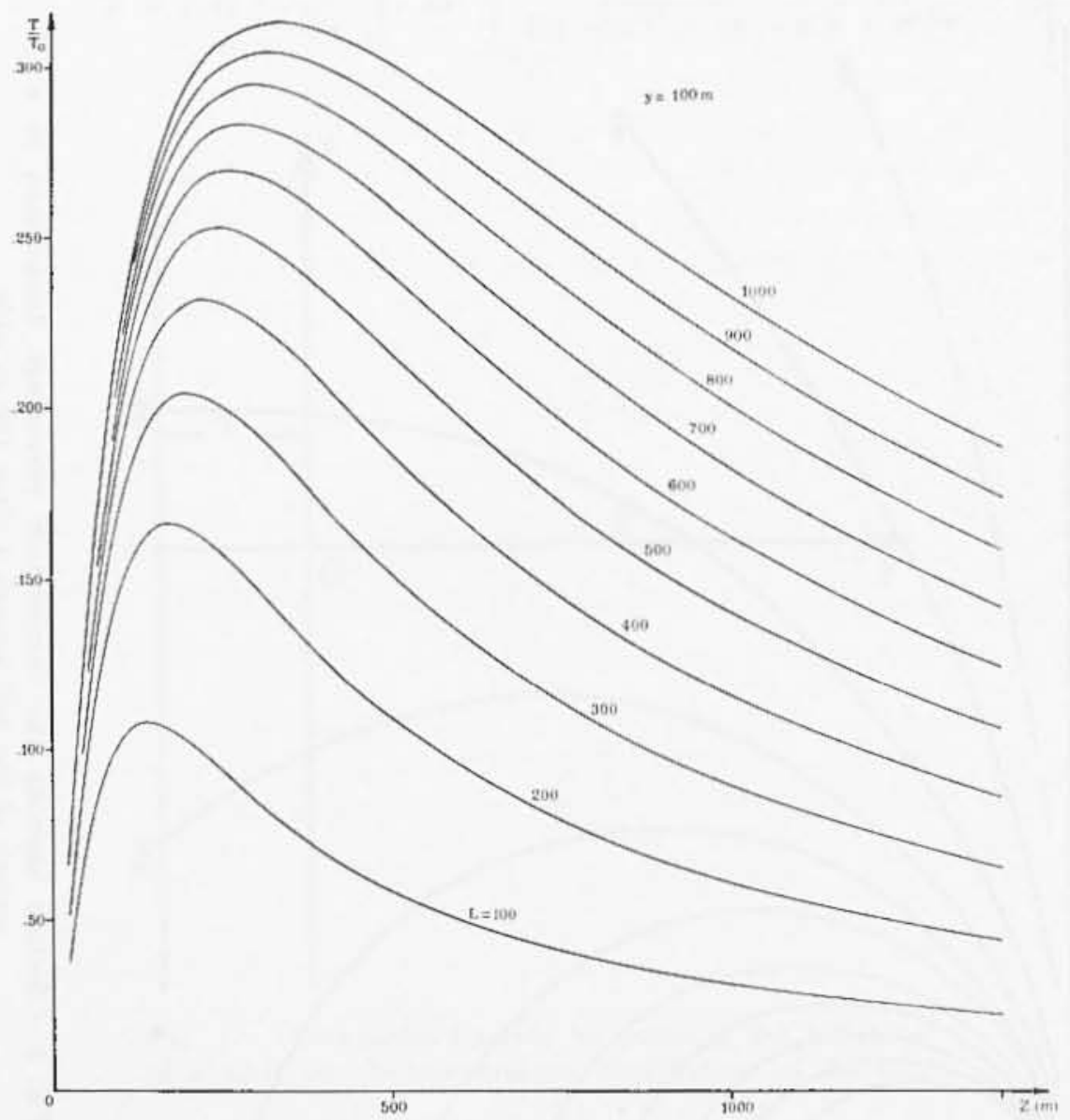

Fig. $3 a, b, e$ - Temperature pereentago disturbanee caused down a bore at distances $y=100,1000$ and $5000 \mathrm{~m}$ from a river 100 106 $1000 \mathrm{~m}$ wide.

Indeed, from [t] we obtain:

$$
\frac{\partial}{\partial z}\left(\frac{T}{T_{o}}\right)=\frac{1}{\pi}\left|\frac{y+L}{(y+L)^{2}+z^{2}}-\frac{y}{y^{2}+z^{2}}\right|
$$

which cancels out for $z-\sqrt{y(L+y)}$. 


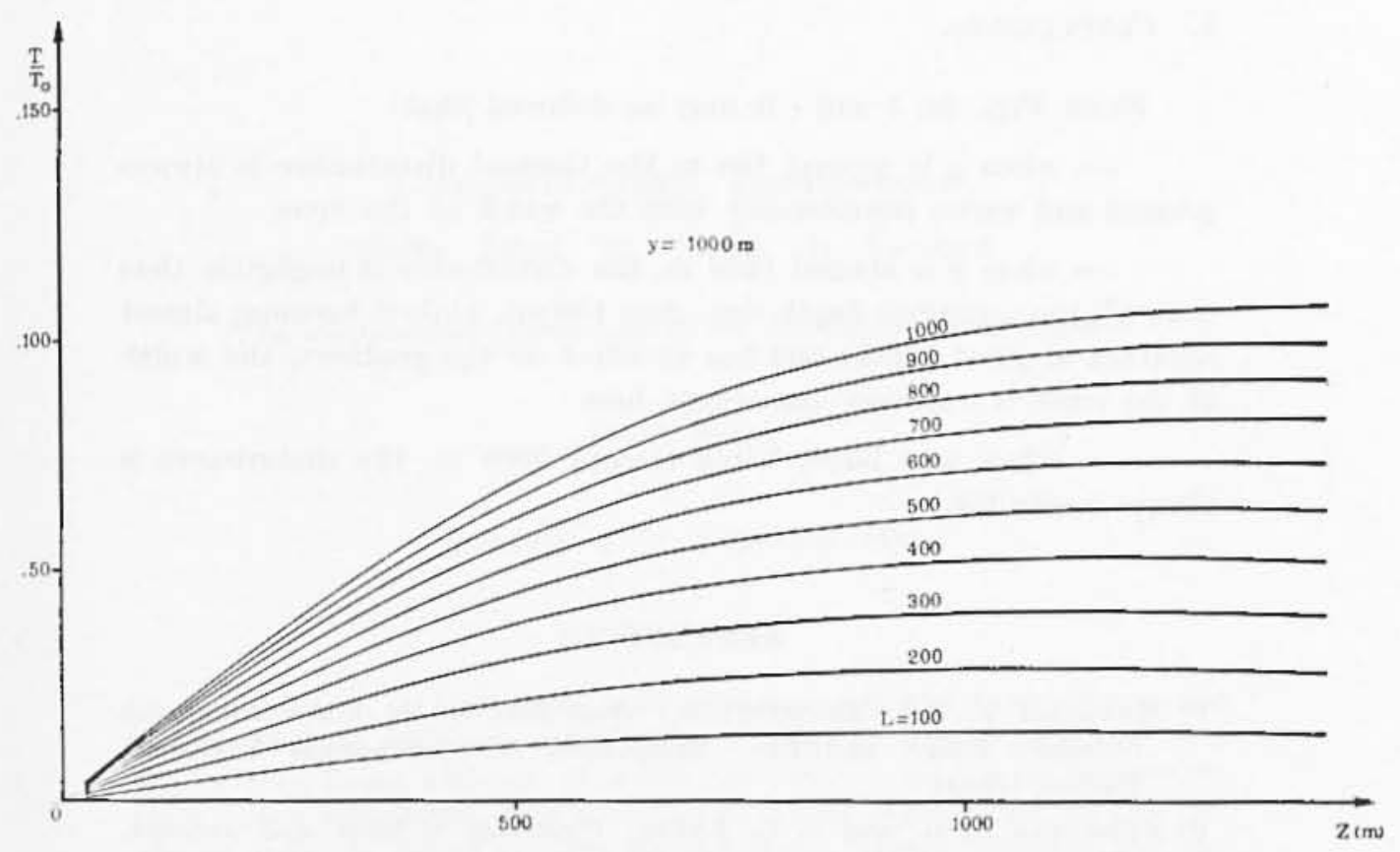

Fig. $3 b$

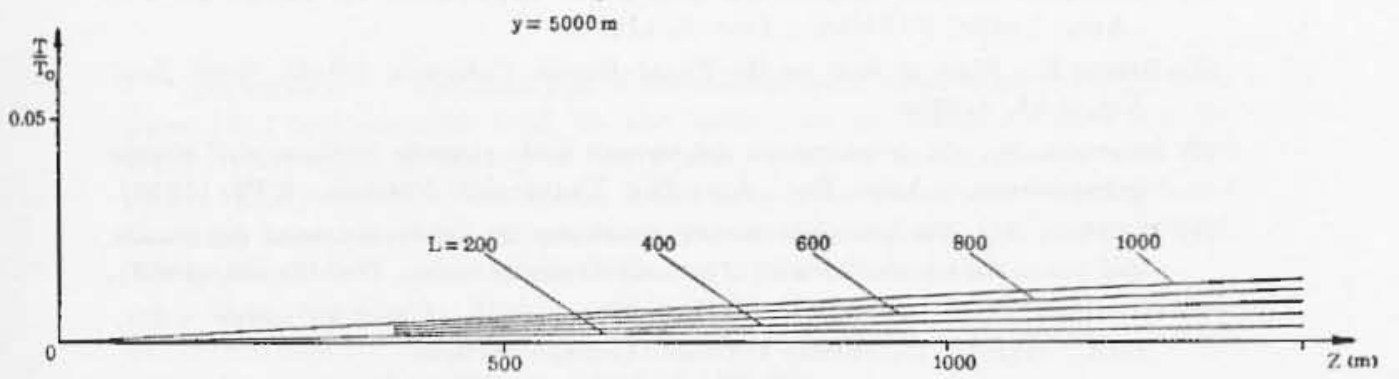

Fig. $3 c$ 


\section{Concuusions.}

From Figs. $3 a, b$ and $c$ it may be deduced ; that:

- when $y$ is around $100 \mathrm{~m}$ the therrtal disturbance is always present and varies sonsiderably with thes width of the river

- when $y$ is around $1000 \mathrm{~m}$, the disturluance is negligible (less than $1 \%$ ) at a shallow depth (less than $100 \mathrm{~m}$ ), while it becornes ahnost constant at great depths and has no sflect on the gradient; the width of the river is not very important heres

- when $y$ is large, being around $5000 \mathrm{~m}$, the disturbance is always negligible.

\section{REFEIRENCES}

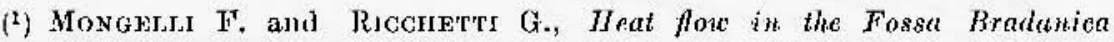
(Southern Italy), IASPEI - Symposium on Geotliermal Problems, Matriıl, (1969).

(2) Zumerce J. H. ant J. C. Arers, Iydrology of lates and swamps. "Von te Chow (Etl.) Ilandbook of applietl hytlrology", Me(iraw-Ilill, (1964).

(3) Surtr K.. Some thermal oharateristics of two rivers in the pennine area of Northern Englaud. "J. Hyslrolory ", VI, 4, (1968).

(1) Prasuchev A. V., Thermal regime of Grimean ricers and infuence on it larst water feeding. "Soviet Hyslrology", 2, (1966).

(5) Tonixr J), Elementi di Larografia e Idrologia, Tol. I e II. a Jibreria Universitaria ". Venezia, (1050).

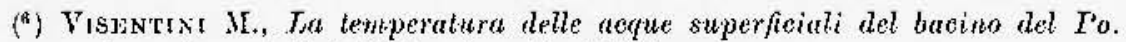
"Alut. Javori l'ubblici ", fasc. 3, (1937).

(7) Bırca F., Flow of heat in the Front Range, Colorado. a Bull. Geol. Soc. Am. " , 61, (195̃o).

(8) Scotros M., La temperabura del terreno nelle ricerehe italiane dell'ultimo quinquenuio. "Anu. Fac. Agraria" Liniversitil Perugia, XIV (1959).

( ${ }^{(5)}$ Macchn F., Un possibite metodo indiretto di determinazione del livello dell'nequa net terreno durane il periodo di siccilà estiva. Webbia, 20, (1965).

(10) Carsiaw H. S., and J. C. JAEGER, Conduction of heat in sotids. "Soc. Eelit., Oxfortl Iniversity "Presis, Joutdon, (1959). 